\title{
Combining Critical Success Factors and Life Cycle Model to Enable Evaluation of e- business models
}

\author{
Helsinki School of Economics, Information System Science \\ Aleksi Horsti \\ aleksi.horsti@kesko.fi
}

\begin{abstract}
Electronic business models (e-business models) are a relatively new and growing research topic within Information Systems Science. The purpose of the paper is to combine critical success factors (CSFs) and life cycle model literature as ways to evaluate e-business models. The study draws empirical data from a survey among leading Finnish companies. In the survey, 104 respondents assessed $20 \mathrm{CSFs}$ gathered from management literature as well as the importance of each CSF at different life cycle stages of an e-business model. Theoretically, the observations give evidence on the changing importance of various CSFs at different stages of an e-business model's life cycle. Primarily, the risk level and effectiveness of e-business model were recognized to distinguish CSFs in the life cycle model. In addition, the customer type (either B2B or B2C), the position in the value chain, and the service or product-orientation seem to affect which CSFs are essential at the various stages of e-business model's life cycle. Managerially, the different weightings of the importance of CSFs in the various stages of an e-business model's life cycle reflect the practical implications of the paper. The results also suggest that different CSFs are crucial at each stage of a life cycle. The results are likely to be useful for the venture capitalists and entrepreneurs in planning and making decisions regarding the long-term scenarios for ebusiness models.
\end{abstract}

\section{Introduction}

Electronic business model (e-business model) research is a relatively young field within information systems science (ISS). When discussing e-business models, the role of information technology in producing opportunities for competitive advantage is seen relevant [36]. During the last few years, the increasing interest in business models has created a need for academic research including definition, taxonomy, description, evaluation, and other relevant topics enhancing the understanding of 
business models. However, several academics have defined the term business model [see e.g. 1, 3, 37, 40, 42]. Some of them have presented a categorization of structural components or the building blocks (i.e. taxonomies) of business models $[3,17,27$, $37,42]$. In addition, lately an interest for evaluating the business models has grown and it has become a relevant area of the business model research $[30,31]$.

The aim of this study is to enhance the understanding of e-business model evaluation as a part of IS research. In the paper, we draw research results from the survey data gathered from the 104 respondents of 60 Finnish companies including 104 business units. Based on the data, we have analyzed $20 \mathrm{CSFs}$ and their behavior at each e-business model's life cycle stage. In addition, the paper will give managerial advices including critical success factors (CSF) to which the management should address its attention. The paper seeks to answer the following research questions:

(i) Do the set of CSFs change in various stages of an e-business model's life cycle?

(ii) Does the life cycle stage affect the importance of a specific CSF?

The paper is organized as follows. The aim of the section two is to review the literature related to e-business models, CSFs, and the life cycle model. In the third section, we present the research methodology and describe the characteristics and demographics of the survey data. In the fourth section, we analyze the survey data regarding the e-business model's life stage mappings. In the remaining sections, we draw conclusions and present the limitations of the study to which we propose avenues for further research.

\section{Literature review}

In the literature review, the most essential research domains are discussed. Firstly, the concept of e-business model is presented. In the second and third sections, the evaluation of e-business models is reviewed in terms of CSFs and life cycle model.

\subsection{E-business Model}

We can observe that originally the business model discussion was initiated by the business simulation game articles [4] in which the abstraction of business was emphasized and seen relevant. Today, the term "business model" has achieved a growing attention being one of the most discussed concepts after the Internet hype of the late 1990's. During the 1990's, business model was mainly used in the context of venture capitalists explaining some of the most unrealistic Internet business models in the daily business news. At the same time, research focusing on the term business model was about to begin.

The first ignitions of business model research were the listings and short descriptions of various generic business model types [e.g. 37, 40]. In addition, several studies adopted a specific view point in which the term business model was used to explain different market structures [27], the continuous change of business 
over time [25, 39], asset portfolio management [7] or the patenting of business models and unique processes [6].

Secondly, another stream of literature on business models emerged recognizing and analyzing the components and elements of a business model. Furthermore, the practical cases and empirical data were utilized for the first time enabling an avenue for convincing academic publications. Weill and Vitale [42] explored eight atomic ebusiness models that can be used as building blocks in multiple ways to create new e-business models. In addition, they introduced a practical way to map an e-business model within one drawing and they emphasized the evaluation of e-business models [42]. In this study, we have adopted the business model definition stated by Weill and Vitale [42]: "the business model is a description of the roles and relationships among a firm's consumers, customers, allies, and suppliers that identifies the major flows of product, information, and money, and the major benefits to participants". In addition, Amit and Zott [3] illustrated three business model constructs - content, structure and governance - basing their research on the strategic management theories and especially on the value creation. Also Afuah and Tucci [1] presented eight business model components and they recognized a need for the evaluation of business models. Osterwalder and Pigneur [30] provided four ontological pillars of an e-business model including product innovation, customer relationship, infrastructure management, and financials following the basic idea of balanced scorecard (BSC) introduced by Kaplan and Norton [19]. Hedman and Kalling [17] presented seven business model components. For the first time, the scope of management was identified as a crucial component of the business model concept. The aim of the component is to describe the dynamics of the business model over time as well as cognitive and cultural constrains that managers have to cope with. All the discussions of the business model components share the notion that a business model is an abstraction of a business identifying how a current business profitably creates value.

Thirdly, according to Osterwalder et al. [30], business model research has lately focused on the practical tools that can be used in management and in IS applications. For example, software-based tools enable the design, visualization, comparison and simulation of complex business models [30]. In addition, the evaluation of ebusiness models has been regarded as a relevant topic in the forthcoming business model studies [31].

\subsection{Critical Success Factors}

The concept of success has been studied throughout a wide range of academic literature [e.g. 9, 13, 40, 42]. The concept of CSFs was developed by Daniel [12] and refined by Rockart [37]. CSFs are the focus areas contributing most to the success of a company and to its competitive position. Therefore, it is crucial for companies to pay attention in managing these factors.

CSFs are regarded as an accepted and widely-used concept [e.g. 2, 22, 33, 34]. CSFs can be regarded as a top-down analysis focusing on a core set of essential 
issues [9]. However, CSFs have also been criticized by academics and practitioners. Especially among academics, the validity of the CSFs concept has been questioned, and among practitioners the complexity of the CSFs concept may finally lead into a too simplified business environment [9].

Despite its shortcomings, CSFs can be seen as a common and recommended basis for the evaluation of success within IS research: defined factors and measures are always required in order to evaluate success. Several studies have gathered empirical data focusing on evaluating the success of a particular IT system implementation [10, 23, 26]. Also information systems [13] and electronic commerce $[14,19,20,41]$ have been interest areas when discussing success.

Peffers et al. [34] developed the CSF concept by coining the term critical success chain (CSC). CSC follows the basics of a three-element model of personal constructs theory [21] including IS attributes, CSF performance, and firm objectives. According to the CSC, if the firm has an aim to enhance a system with certain attributes, the use of the system will result in outcomes that are observable as changed CSF performance, which is, in turn, required to achieve relevant firm objectives [34].

\subsection{Life cycle model}

The product life cycle (PLC) concept is described as the evolution of a product, as measured by its sales over time [11, 18, 24, 32]. Patton [30] went further and described that the main idea is to create a basis for planning the strategy of profitable product exploitation. According to Levitt [24] and Cox [11], different strategies are adopted at the various stages of a product life cycle. After this, different strategic actions of each life cycle stage were included [18]. Thus, these studies indicate that management has to focus on different issues in the early phase compared to the maturity phase of a product's life cycle.

Life cycle model has been widely adopted in other disciplines too. Within the IS science, the life cycle model has been used, for example, in the context of the computer-based information systems [29], systems development [28] as well as business process re-engineering [23]. According to Ginzberg [16], the implementation of information systems is not a discrete event or activity that can be evaluated or studied with simple research approaches at one point of time, since attitudes and beliefs may change over the various stages of the implementation process. Furthermore, most of the e-business model studies have adopted a static view on e-business models rather than the adoption of development, dynamics and maturity of a business model along time [8]. Hence, this is one of the first studies to introduce the life cycle model in the context of e-business models.

\section{Methodology}

The section discusses the study design. Also the demographics of the respondents are presented. 


\subsection{Data collection and sample}

We gathered data for the study from various sources being the expert interviews, a literature review, the pilot testing of the questionnaire, and the subsequent survey. Firstly, we began the empirical study in the fall 2003 with qualitative research methods. We interviewed 17 managers from five e-business models representing five industries: paper, media, traveling, telecom, and logistics. The main purpose of these interviews was to identify CSFs affecting their e-business models. At the same time, a literature review was conducted analyzing previous success factor studies from the academic journal articles. However, after the interviews and literature review we had a raw listing of CSFs. Next, the number of initial CSFs was reduced by excluding the duplicates and similar factors.

Secondly, we decided to include the CSFs from the interviews and literature as variables in the pilot-test survey. The questionnaire was pilot-tested by ten chosen experts representing both practitioners and academics. Thirdly, the questionnaires were sent by mail to the respondents. In the questionnaire, a respondent was able to choose one or several life cycle stages indicating the existing relevance of the current success factor at a particular stage of the life cycle. In this study, the stages of a business model's life cycle were defined as introduction, growth, maturity, and decline following the concept of PLC [e.g. 18, 32]. In addition, common questions related to the basic demographic data were included.

In this research, the unit of analysis is a business unit, since on the company level there may exist more than one business model whereas on the business unit level it is typical to have only one business model. However, we chose a sample of 450 managers representing 450 business units in 61 companies. All the respondents were practitioners on the managerial levels of their organization, and they all had experience from electronic business. The respondents were chosen from Finnish international companies following two criteria: 1) the company is among the top 30 Finnish companies according to their revenue and/or 2) the company is listed among the top 100 on-line brands in Finland. Finally, we had a list of 450 business units from 61 companies including various industries, traditional large companies as well as some of the most successful small e-commerce and portal companies.

\subsection{Demographics}

The total number of responses amounted to 104 out of the 450 questionnaires, which yielded a 23-percent response rate. We received properly filled questionnaires from 60 companies including 104 business units. Respondents worked primarily (46\%) on the managerial level of the organization, or as directors $(29 \%)$. Forty-five percent of the respondents had five to nine years of valid e-business experience, while 23 percent had as much as ten years or more of e-business experience.

Most of the business units in the sample have a long tradition of using EDI in their business operations. In many traditional manufacturing business units, EDI is still seen as a crucial component of e-business. Eighty percent of the business units 
had started using EDI before 1993 and the Internet was used by 95 percent of the business units.

\section{Analysis and results}

In assessing the CSFs, we adopted the life cycle model to distinguish the importance of a particular CSF at the different stages of an e-business model's life cycle. In this section, we present the analysis and results of the study.

\subsection{E-business model's life cycle}

Our analysis is based on a questionnaire in which we asked respondents to choose one or more life cycle stages, including introduction, growth, maturity, and decline, at which a respondent sees a particular CSF as crucial. By allowing respondents to choose as many stages as they found relevant, we prevented unnecessary limitations from the respondent's point of view.

Table 1. Importance of CSFs in each life cycle stage.

\begin{tabular}{|c|c|c|c|c|c|}
\hline & $\begin{array}{l}\text { CRITICAL SUCCESS FACTOR } \\
\text { OF E-BUSINESS MODEL }\end{array}$ & \multicolumn{4}{|c|}{$\begin{array}{l}\text { E-BUSINESS MODEL'S LIFE CYCLE } \\
\text { STAGE }\end{array}$} \\
\hline V1 & $\begin{array}{l}\text { E-business related personnel is highly } \\
\text { experienced }\end{array}$ & $43 \%$ & $76 \%$ & $48 \%$ & $22 \%$ \\
\hline V2 & $\begin{array}{l}\text { E-business related personnel } \\
\text { possesses relevant know-how and } \\
\text { capabilities }\end{array}$ & $63 \%$ & $90 \%$ & $45 \%$ & $26 \%$ \\
\hline V3 & $\begin{array}{l}\text { E-business model can be regarded as } \\
\text { an innovative forerunner in terms of } \\
\text { products, services and technology }\end{array}$ & $64 \%$ & $61 \%$ & $24 \%$ & $11 \%$ \\
\hline V4 & $\begin{array}{l}\text { The e-business model related } \\
\text { customer data is gathered and utilized }\end{array}$ & $49 \%$ & $70 \%$ & $50 \%$ & $35 \%$ \\
\hline V5 & $\begin{array}{l}\text { E-business model related software } \\
\text { and hardware are stabile }\end{array}$ & $39 \%$ & $78 \%$ & $69 \%$ & $30 \%$ \\
\hline V6 & $\begin{array}{l}\text { E-business model related multi- } \\
\text { channel environment is well-managed } \\
\text { including both the traditional and } \\
\text { electronic channels }\end{array}$ & $35 \%$ & $68 \%$ & $55 \%$ & $23 \%$ \\
\hline V7 & $\begin{array}{l}\text { Systematic risk management } \\
\text { minimizing the vulnerability of e- } \\
\text { business model is regarded relevant }\end{array}$ & $54 \%$ & $68 \%$ & $53 \%$ & $35 \%$ \\
\hline V8 & $\begin{array}{l}\text { E-business model related } \\
\text { management accomplishes well } \\
\text { networking and partnering relations }\end{array}$ & $48 \%$ & $76 \%$ & $49 \%$ & $23 \%$ \\
\hline V9 & The quality of products and services & $40 \%$ & $72 \%$ & $73 \%$ & $34 \%$ \\
\hline
\end{tabular}


of e-business models

\begin{tabular}{|c|c|c|c|c|c|}
\hline & in e-business model is good & & & & \\
\hline V10 & $\begin{array}{l}\text { Products and services in the e- } \\
\text { business model are easily accessible } \\
\text { and usable }\end{array}$ & $52 \%$ & $77 \%$ & $58 \%$ & $22 \%$ \\
\hline V11 & $\begin{array}{l}\text { E-business model related operation } \\
\text { and products / services offered have a } \\
\text { strong brand in the market }\end{array}$ & $48 \%$ & $69 \%$ & $47 \%$ & $15 \%$ \\
\hline V12 & $\begin{array}{l}\text { E-business model related customer } \\
\text { needs are identified and understood }\end{array}$ & $51 \%$ & $79 \%$ & $59 \%$ & $35 \%$ \\
\hline V13 & $\begin{array}{l}\text { E-business model's offering is } \\
\text { targeted and customized }\end{array}$ & $42 \%$ & $47 \%$ & $55 \%$ & $27 \%$ \\
\hline V14 & $\begin{array}{l}\text { E-business model related } \\
\text { management is committed }\end{array}$ & $64 \%$ & $69 \%$ & $41 \%$ & $27 \%$ \\
\hline V15 & $\begin{array}{l}\text { Management has valuable capabilities } \\
\text { in managing the e-business model }\end{array}$ & $57 \%$ & $70 \%$ & $36 \%$ & $30 \%$ \\
\hline V16 & $\begin{array}{l}\text { E-business model's operations and } \\
\text { processes are cost efficient }\end{array}$ & $22 \%$ & $52 \%$ & $71 \%$ & $47 \%$ \\
\hline V17 & $\begin{array}{l}\text { Decisions regarding the competitive } \\
\text { strategy of e-business model are } \\
\text { evident being either cost leadership or } \\
\text { differentiation strategy }\end{array}$ & $27 \%$ & $72 \%$ & $66 \%$ & $22 \%$ \\
\hline V18 & $\begin{array}{l}\text { E-business model's customers are } \\
\text { satisfied and loyal }\end{array}$ & $32 \%$ & $70 \%$ & $75 \%$ & $45 \%$ \\
\hline V19 & $\begin{array}{l}\text { IT operations and security in terms of } \\
\text { software and hardware are reliable } \\
\text { from internal point of view }\end{array}$ & $58 \%$ & $71 \%$ & $78 \%$ & $50 \%$ \\
\hline V20 & $\begin{array}{l}\text { IT operations and security in terms of } \\
\text { software and hardware are reliable } \\
\text { from external point of view }\end{array}$ & $64 \%$ & $78 \%$ & $71 \%$ & $53 \%$ \\
\hline & ALL VARIABLES & $44 \%$ & $70 \%$ & $57 \%$ & $31 \%$ \\
\hline
\end{tabular}

In investigating all the variables at the e-business model's four life cycle stages, results indicate that the growth stage is at the center of interest $(70 \%)$ and on the contrary the decline stage ( $31 \%$ ) gets the least attention. In reviewing specific CSFs, we discover that The innovativity of e-business model (V3) is the most emphasized in the early stages of an e-business model's life cycle. In the growth stage of the life cycle, The capabilities of personnel and management (V2, V15) are tested in an ebusiness environment where competition becomes challenging for any e-business model. An e-business model also has to show its competitiveness in terms of The ease-of-use of products and services as well as in The fulfillment of customer needs (V10, V12). In the maturity phase, Customer satisfaction and loyalty (V18) are stressed. In addition, customers are seeking $A$ reliable offering with high quality (V9) in which the role of Targeted and customized offering (V13) is becoming essential. In the decline stage of an e-business model's life cycle, the most essential factor is 
Cost efficiency (V16). As expected, The reliability of IT operation and security (V19, V20) seems to be relevant during all stages.

We continued the analysis by reviewing the combinations of each life cycle stage markings (see Table 2). Altogether, the respondents had 15 options from which to choose a proper combination of life cycle stages that they regard relevant for a specific CSF. This way, we were able to identify the number of the life cycle stage markings for all the $20 \mathrm{CSF}$. Due to the large number of options, we aimed at focusing on the most essential combinations by grouping them into the four groups: G1 - Introduction \& Growth, G2 - Growth \& Maturity, G3 - Maturity \& Decline, and G4 - All the life cycle stages. In addition, we excluded the options (i.e. Options: 5, 8, $9,10,11$ and 13) having less than 21 markings (see Table 2, the sum of V1-V20 column). Hence, out of the 15 options, nine were taken into account in the groupings (G1, G2, G3 and G4) for the further analysis.

Table 2. Frequencies of life cycle stage mappings.

\begin{tabular}{|c|c|c|c|c|c|c|}
\hline Option & Intro & Growth & Maturity & Decline & Group* & Sum of V1-V20 \\
\hline 1 & $\mathrm{X}$ & & & & G1 & 190 \\
\hline 2 & & $\mathrm{X}$ & & & G1 & 359 \\
\hline 3 & $\mathrm{X}$ & $\mathrm{X}$ & & & G1 & 295 \\
\hline 4 & & & $\mathrm{X}$ & & G3 & 279 \\
\hline 5 & $\mathrm{X}$ & & $\mathrm{x}$ & & 0 & 8 \\
\hline 6 & & $\mathrm{X}$ & $\mathrm{x}$ & & G2 & 199 \\
\hline 7 & $\mathrm{X}$ & $\mathrm{X}$ & $\mathrm{X}$ & & $\mathrm{G} 2$ & 99 \\
\hline 8 & & & & $\mathrm{X}$ & 0 & 13 \\
\hline 9 & $\mathrm{X}$ & & & $\mathrm{x}$ & 0 & 20 \\
\hline 10 & & $\mathrm{X}$ & & $\mathrm{X}$ & 0 & 13 \\
\hline 11 & $\mathrm{X}$ & $\mathrm{X}$ & & $\mathrm{X}$ & 0 & 11 \\
\hline 12 & & & $\mathrm{X}$ & $\mathrm{X}$ & G3 & 92 \\
\hline 13 & $\mathrm{X}$ & & $\mathrm{x}$ & $\mathrm{x}$ & 0 & 3 \\
\hline 14 & & $\mathrm{X}$ & $\mathrm{X}$ & $\mathrm{X}$ & G4 & 118 \\
\hline 15 & $\mathrm{X}$ & $\mathrm{X}$ & $\mathrm{x}$ & $\mathrm{x}$ & G4 & 356 \\
\hline
\end{tabular}

*) Value labels; G1=Introduction\&Growth; G2=Growth\&Maturity; G3=Maturity\&Decline; G4=All stages

\subsection{Correspondences between life cycle stages and variables}

In order to illustrate the situation between the 20 variables and four life cycle stage groups, we decided to use correspondence analysis (Figure 1). The variables are adequately plotted (Sig. 0.000 ) in the two-dimension correspondence analysis explaining $85.5 \%$ of the variation. Dimension 1 explains $56.4 \%$ of the variation. On the first dimension, The innovativity of e-business model (V3) is plotted far left whereas The reliability of IT operations and security (V19, V20) on the right. Evidently, the risk level of the e-business model seems to become the most essential dimension to categorize all the variables in the correspondence analysis. Dimension 2 explains $29.1 \%$ of the variation in which The capabilities of personnel and management (V2, V15) are plotted on the top of the matrix and Cost efficiency (V16) and Targeted and customized offering (V13) on the bottom. We regard that the 
efficiency of an e-business model seems to spread the variables along the Dimension 2.

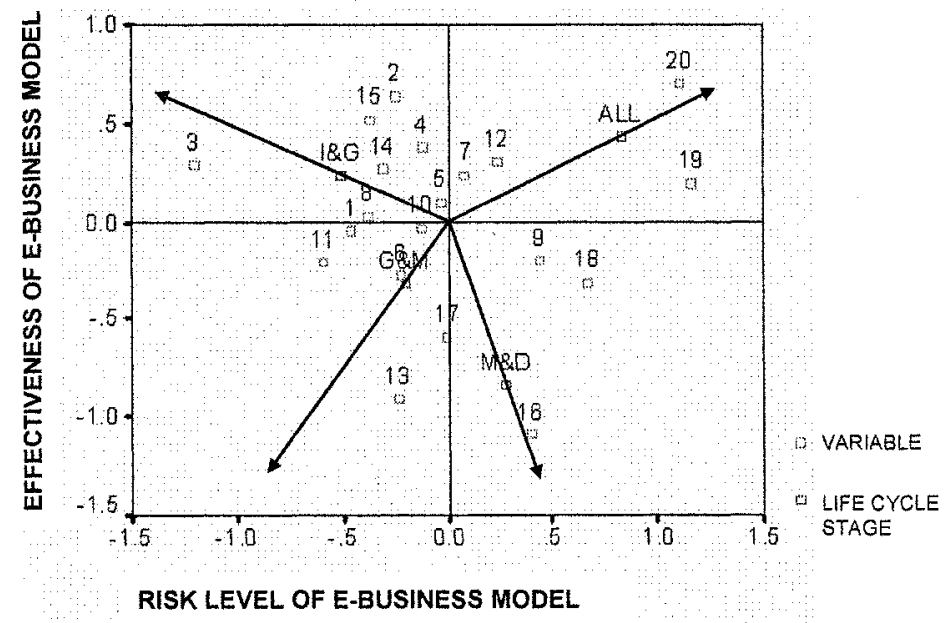

Fig. 1. Correspondence analysis.

According to the correspondence analysis, we can derive the following results. The innovativity of e-business model (V3) and Capabilities of management (V15) are crucial in the introduction and growth stages. Furthermore, Chosen competitive strategy (V17) is stressed in the growth and maturity stages and Cost efficiency (V16) in the maturity and decline stages. Finally, The reliability of IT operation and security (V19, V20) are significantly emphasized during all the stages of the life cycle.

\subsection{Combining e-business model's background with life cycle stages}

In the earlier sections, we discussed the four groups formed based on the life cycle stage including Introduction \& Growth (G1), Growth \& Maturity (G2), Maturity \& Decline (G3), and All the life cycle stages (G4). We were also interested in comparing the groups against the characteristics of the respondent's e-business model, In order to distinguish the various life cycle stages, we excluded the G4 from the analysis. The analysis was accomplished with One-Way ANOVA.

Firstly, we examined the customer type of the e-business model being either B2B or $\mathrm{B} 2 \mathrm{C}$. The respondents representing $\mathrm{B} 2 \mathrm{C}$-focused e-business models see that risks should be managed (V7, V19) earlier in the life cycle compared to the 
representatives of $\mathrm{B} 2 \mathrm{~B}$-focused e-business models. The result could be explained by the notion that generally the risk management is more enhanced in the $\mathrm{B} 2 \mathrm{~B}$-focused e-business models, since both the transacting companies have to manage their risks. On the contrary, IT security and reliability have to be considered with the B2Cfocused e-business models earlier compared to the B2B ones, since most of the consumers are not always aware of the data security related matters.

Secondly, we examined the variances between the e-business models having an offering that includes either products or services. The analysis demonstrates that Customer satisfaction and loyalty (V18), as well as Advanced and well-managed multi-channel environment (V6) are likely to be more crucial variables for the product-oriented e-business models earlier in the e-business model's life cycle compared to the service-oriented e-business model.

Thirdly, we studied e-business model's life cycle stages by analyzing the position of e-business model in the value chain. We followed the categorization made by Benjamin and Wigand [5]. The early phase of the value chain is a producer, the middle phase is a wholesaler, and the final phase is a retailer. For the producer-type of e-business models, Advanced and well-managed multi-channel environment (V6) with Satisfied and loyal customers (V18) is more relevant in the early stage of the ebusiness model's life cycle compared to the retailer-type of e-business model. The results show that the producer-type of e-business model typically is a productoriented e-business model with B2B customers. In addition, the producer-type of ebusiness models need to target and customize their offering (V13) earlier compared to the retailer-type of e-business models, since the B2B-type of customers are likely to require targeted and customized offerings more compared to the $\mathrm{B} 2 \mathrm{C}$ ones that are seeking mainly standardized offerings.

Table 3. Analysis of One-Way ANOVA

\begin{tabular}{|ll|cccc|}
\hline Variable & Grouping criteria & N & Mean $^{*}$ & F & Sig. \\
\hline V7 & B2B & 49 & 2.02 & 3.92 & .052 \\
& B2C & 16 & 1.69 & & \\
\hline V19 & B2B & 37 & 2.14 & 3.66 & .062 \\
& B2C & 11 & 1.55 & & \\
\hline V6 & Product oriented & 30 & 1.43 & 5.67 & .020 \\
& Service oriented & 52 & 1.88 & & \\
\hline V18 & Product oriented & 23 & 1.61 & 8.83 & .004 \\
& Service oriented & 44 & 2.25 & & \\
\hline V6 & Producer & 32 & 1.41 & 3.81 & .026 \\
& Wholesal./Intermed. & 13 & 1.92 & & \\
& Retailer & 37 & 1.92 & & \\
\hline V13 & Producer & 36 & 1.67 & 2.67 & .075 \\
& Wholesal./Intermed. & 14 & 1.86 & & \\
& Retailer & 40 & 2.15 & & \\
\hline V18 & Producer & 25 & 1.60 & 8.41 & .001 \\
& Wholesal./Intermed. & 12 & 1.83 & & \\
& Retailer & 30 & 2.47 & & \\
\hline
\end{tabular}


*) Value labels: 1=Introduction\&Growth; 2=Growth\&Maturity; 3=Maturity\&Decline

\section{Discussion and conclusion}

This research presents evidences that CSFs seem to be different in the various stages of e-business model's life cycle. The two main dimensions to categorize both CSFs and life cycle stages are the risk level and the effectiveness of an e-business model. Some of the CSFs are likely to be stressed in the early stages of the life cycle whereas others are essential in the latter part of the life cycle. In addition, the business environment (e.g. customer type and position in the value chain) seems to affect CSFs that are selected as crucial. Hence, these interesting results enable us to derive both the theoretical and managerial implications.

The theoretical contribution of the research can be divided into three issues. Firstly, we have combined the CSFs and the stages of life cycle for the first time as a way to evaluate e-business models within IS. Both of them are well-known and recognized in several academic studies [2, 8, 34] despite the recognized shortcomings [9]. Secondly, in synchronizing the CSFs and the stages of a life cycle model, it gives us an opportunity to underpin the characteristics of an e-business model's life cycle as well as to gain an understanding of e-business models. Thirdly, the customer type (either $\mathrm{B} 2 \mathrm{~B}$ or $\mathrm{B} 2 \mathrm{C}$ ), the position in the value chain, and the service or product-orientation seem to affect what CSFs are chosen to be essential in the different stages of e-business model's life cycle.

The managerial implications are clear. Results regarding the importance of various CSFs in each stage of an e-business model's life cycle may offer practical insights for the managers. It is crucial to understand that CSFs will change when an e-business model matures. In other words, the focus areas are different in the early stage of e-business model's life cycle compared to the latter parts. The results may also be useful for the venture capitalists and entrepreneurs evaluating or planning new e-business models in the long-term.

Like most survey studies, this study is subject to limitations. Firstly, the sample consisted of only Finnish firms operating in local and international markets. Hence, a larger sample including companies and their business models from other countries would give a richer picture of the subject matter. Secondly, although we sent out an equal number of questionnaires to large companies (top 30 Finnish firms), the number of responses received from the companies varied. For example, we received nine responses from the Finnish Post and only two from Nokia. This is a typical challenge in all the studies utilizing the survey as a primary data collection technique. 


\section{References}

1. A. Afuah and C. Tucci, Internet Business Models and Strategies: Text and Cases (McGraw-Hill Companies, New York 2001).

2. H. Akkermans, and K. van Helden, Vicious and Virtuous Cycles in ERP Implementation: A Case Study of Interrelations between Critical Success Factors, European Journal of Information Systems 11(1), 35-46 (2002).

3. R. Amit and C. Zott, Value Creation in E-Business, Strategic Management Journal 22(6/7), 493-520 (2001).

4. R. Bellman, C.E. Clark, D.G. Malcolm et al. On the Construction of a Multistage, Multi-person Business Game, Operations Research, 5(4), 469-503 (1957).

5. R. Benjamin and R. Wigand, Electronic Markets and Virtual Value Chains on the Information Superhighway, Sloan Management Review, 36(2), 62-72 (1995).

6. K. Beresford, European Patents for Software, E-commerce and Business Model Inventions, World Patent Information, 23(3), 253-263 (2001).

7. R.E. Boulton and B.D. Libert, A Business Model for New Economy, The Journal of Business Strategy, 21(4), 29-35 (2000).

8. H. Bouwman and I. MacInnes, Dynamic Business Model Framework for Value Webs, Proceedings of the 39th Hawaii International Conference on System Sciences, Hawaii, USA, 2006.

9. A.C. Boynton and R.W. Zmud, An Assessment of Critical Success Factors, Sloan Management Review, 25(4), 17-27 (1984).

10. A.L. Cavaye and P.B. Cragg, Factors Contributing to the Success of Customer Oriented Interorganizational Systems, The Journal of Strategic Information Systems 4(1), 13-30 (1995).

11. W.E. Cox Jr, Product Life Cycles As Marketing Models, Journal of Business, 40(4), 375-384 (1967).

12. D.R. Daniel, Management Information Crisis, Harvard Business Review, 39(5), 111-121 (1961).

13. W.H. DeLone and E.R. McLean, Information Systems Success: The Quest for the Dependent Variable, Information Systems Research, 3(1), 60-95 (1992). 
14. W.H. DeLone and E.R. McLean, The DeLone and McLean Model of Information Systems Success: A Ten-Year Update, Journal of Management Information Systems, 19(4), 9-30 (2003).

15.P.Doyle, What are the Excellent Companies? Journal of Marketing Management $8(2), 101-116(1992)$.

16. M.J. Ginzberg, Early Diagnosis of MIS Implementation Failure: Promising Results and Unanswered Questions, Management Science, (27), 459-478 (1981).

17. J. Hedman and T. Kalling, The Business Model Concept: Theoretical Underpinnings and Empirical Illustrations, European Journal of Information Systems 12(1), 49-59 (2003).

18. C.W. Hofer, Toward a Contingency Theory of Business Strategy, Academy of Management Journal, 18(4), 784-810 (1975).

19. R.S. Kaplan and D.P. Norton, The Balanced Scorecard - Measures that Drive Performance, Harvard Business Review, 70(1), $71-79$ (1992).

20. R.L. Keeney, The Value of Internet Commerce to the Customer, Management Science, 45(4), 533-542 (1999).

21. G.A. Kelly, The P.sychology of Personal Constructs (New York: W.W. Norton, 1955).

22. S.F. King and T.F. Burgess, Beyond Critical Success Factors: A Dynamic Model of Enterprise System Innovation, International Journal of Information Management, 26(1), 59-69 (2006).

23. M.A. Larsen and M.D. Myers, When Success Turns into Failure: A Packagedriven Business Process Re-engineering Project in the Financial Services Industry, The Journal of Strategic Information Systems 8(4), 395-417 (1999).

24. T. Levitt, Exploit the Product Life Cycle, Harvard Business Review 43(6), 81-94 (1965).

25. J.C. Linder and S. Cantrell, Five Business-Model Myths that Hold Companies Back, Strategy and Leadership, 29(6), 13-18 (2001).

26. H.C. Lucas Jr, Empirical Evidence for a Descriptive Model of Implementation, MIS Quarterly, (2), 27-42 (1978).

27. B, Mahadevan, Business Models for Internet-Based E-Commerce: An Anatomy, California Management Review, 42(4), 55-69 (2000). 
28. M.M. Mantei and T.J. Teorey, Incorporating Behavioral Techniques into the Systems Development Life Cycle, MIS Quarterly, 13(3), 257-274 (1989).

29. C.R. Necco, C.L. Gordon and N.W. Tsai, Systems Analysis and Design: Current Practices. MIS Quarterly, 11(4), 461-476 (1987).

30. A. Osterwalder, Y. Pigneur and C.L. Tucci, Clarifying Business Models: Origins, Present, and the Future of the Concept, Communications of the Association for Information Systems, (16), 1-25 (2005).

31. A.G. Pateli and G.M. Giaglis, A Reasearch Framework for Analysing eBusiness Models, European Journal of Information Systems, 13(4), 302-314 (2004).

32. A. Patton, Stretch Your Product's Earnings Years: Top Management's Stake in the Product Life Cycle, Management Review (48), 67-79 (1959)

33. D. Peak, C.S. Guynes and V. Kroon, Information Technology Alignment Planning - A Case Study, Information \& Management, 42(4), 619-633 (2005).

34. K. Peffers, C.E. Gengler and T. Tuunanen, Extending Critical Success Factors Methodology to Facilitate Broadly Participative Information Systems Planning, Journal of Management Information Systems, 20(1), 51-85 (2003).

35. M. Porter, Competitive Strategy: Techniques for Analyzing Industries and Competitors (The Free Press, New York, 1980).

36. M. Porter and V.E. Millar, The Information Revolution is Transforming the Nature of Competition - How Information Gives You Competitive Advantage, Harvard Business Review, 149-174, July-August (1985).

37. M. Rappa, Managing the Digital Enterprise - Business Models on the Web, North Carolina State University, 2001. Accessed May 2006 http://digitalenterprise.org/models/models.html

38. J.F. Rockart, Chief Executives Define Their Own Data Needs, Harvard Business Review 57(2), 81-93 (1979).

39. H. Singh, V. Sethi and V. Sethi, Changing Inside, Watching Outside: Understanding Business Model Adaptations to Guide Information Technology Decisions, Proceedings of the 26th International Conference on Information Systems, December 11-14, 2005, Las Vegas, USA.

40. P. Timmers, Business Models for Electronic Markets, Electronic Markets 2(2), 3 8 (1998). 
41. G. Torkzadeh and G. Dhillon, Measuring Factors that Influence the Success of Internet Commerce, Information Systems Research 13(2), 187-204 (2002).

42. P. Weill and M. Vitale, Place to Space - Migrating to eBusiness Models (Harvard Business School Press, Boston, 2001). 